TURIZAM

Volume 20, Issue 4

180-191 (2016)

ORIGINAL

SCIENTIFIC PAPER

\title{
Gastronomic Tourism in Rural Areas of Vojvodina (Serbia)
}

\author{
Maja Banjac ${ }^{A}$, Bojana Kalenjuk ${ }^{A}$, Dragan TešanovićA ${ }^{A}$ Snježana Gagić ${ }^{B}$, Biljana Cvetkovićc* \\ Received: October 2016 | Accepted: December 2016 \\ DOI: 10.18421/TRZ20.04-02
}

\begin{abstract}
The food is basically a physiological need of people. However it has been increasingly enjoyed by gourmets thus satisfying their hedonistic needs and creating the basis for a tourist trip. For food to be the motive for the arrival of tourists, it must be different from the food offered in the daily environment of living, and it is expected that such food exists in rural areas. Research of gastronomic potential in rural areas was carried out in the region of Vojvodina (northern Serbia), which is a multicultural tourist area where there are around thirty different nations, which through history, living in this plain, fertile area, influenced the formation of the rich and varied gastronomy. The aim of this papir is to examine the tourism potentials that could attract rich gastronomic tourists to rural areas, in order to support the development of countrysides of the region.
\end{abstract}

Keywords: gastronomy, food, tourism, rural, potential, development

\section{Introduction}

Tourism is a branch of the economy which has significant social and economic functions of a certain area and as such contributes to highlighting and better evaluation of agricultural environment in which food is an essential resource (Henderson, 2004; Quan, Wang, 2004). Taking into account the basic characteristics of gastronomic tourism as an increasingly massive form of movement of tourists, the focus of interest in addition to a variety of bids of big metropolises are villages and rural households where food comes from. New trends are slowly turning attention from the mass tourism to alternative forms, thus food and drinks that are an integral part of all forms of tourism, become the primary motive for coming to a particular des-

A Department of Geography, Tourism and Hotel Management; Faculty of Sciences; University of Novi Sad, Trg Dositeja Obradovića 3, 21000 Novi Sad, Serbia;

maja.banjac@dgt.uns.ac.rs; bojana.kalenjuk@dgt.uns.ac.rs; dragan.tesanovic@dgt.uns.ac.rs

B College of professional studies in management and business communication, Mitropolita Stratimirovića 110, 21205 Sremski Karlovci, Serbia; gagicsnjeza@yahoo.com

c Secondary Hospitality School, Jug Bogdanova 28, 11000 Beograd, Serbia.

Corresponding author: biki_cvet@yahoo.com 
tination (Kalenjuk, et al., 2014a). Through gastronomy preserved in the villages, tourists learn about the culture and customs of the visited area, but also the characteristic tastes and flavors that give an authentic experience. Many tourist agencies have recognized potentials of gastronomy in which they operate included them in their offers of rural areas, developing selective form of tourism, known in the world as a food tourism (Boniface, 2003) or gastronomic (Hjalanger, Richards, 2002), culinary (Wolf, 2006; Ignatov, Smith, 2006), gustatory (Boniface, 2003) and gourmet tourism.

Movements of gastronomic tourists are realized by visits and gustations at primary and secondary food and beverage manufacturers, visiting the festivals of food and beverage and by consumption of authentic specialties in different restaurants, and increasingly popular form of gastronomic tourism is an activity of tourists in the preparation of dishes through the various schools of authentic regional cooking (Hall, Mitchell, 2006). Agritourism is a subset of rural tourism but also of gastronomic tourism, and gastronomic tourism is different from agritourism because is a subset of cultural tourism (cuisine is a part of culture). However, gastronomic tourism and agrotourism are inextricably linked. Similarly, some authors consider wine and beer tourisms as subsets of gastronomic tourism because this type of tourism includes the consumption of drinks and beverages (Hall, 2003; Wolf, 2006).

The need for researching gastronomic potentials in rural areas stem from the fact that Vojvodina is a major tourist area in Serbia, where there are around thirty nations, which is due to dynamic historical events contributed to the occurrence of various forms of specificity (living traditions, customs, religion, way of doing business etc.), which combined with the fertile plain influenced the formation of the rich and varied gastronomy.

The subject of this study are potentials of the food and beverage of multicultural villages of Vojvodina, which per se, beside primary reason of attracting tourists, can attract rich gastronomic tourists and thus ensure faster development of countrysides.

The task of the paper is to explore the nutritional potentials of Vojvodina countrysides, aiming to draw attention to underutilized opportunities in rural areas to contribute to the development of the region, through the development of gastronomic tourism.

\section{Literature review}

\section{Contrysides as a basis for development of gastronomic tourism}

The areas in which technological wave and globalization did not influence significantly the changes in the way of food and beverage production, and the culture of their consumption, have become favorable for the development of tourism of food and beverage, culinary tourism, gastronomic tourism and gourmet tourism (Hall, Mitchell, 2002). These forms represent a special form of tourism which aims to bring tourists motivated by food and drinks in different ways, making food an important tool in the tourism industry (Hall, Mitchell, 20oo) which in order to further develop and grow, it had to offer something different such as local and national dishes and drinks as a reflection of the culture of a nation which is still kept only in the villages (Stojanović, Čerović, 2008; Kalenjuk, et al., 2012a).

Gastronomic and culinary tourism is defined as a trip in which the purchase or consumption of regional food (and drink), or observation and study of food production (from agriculture to culinary school) is an important motive or activity (Ignatov, Smith, 2006). Gastronomic tourists visit places which offer them unique culinary experiences, they like to get into the 
kitchen of the host, to learn about the typical dishes, where they can purchase groceries and spices from dishes of visited destination (Kalenjuk, et al., 2012b) and in that way they support villages and rural households (Baum, 2011; Kalenjuk, Tešanović, 2013c).

\section{Importance of food in development of tourism}

The popularity of tourism for food and wine is in the world known for several decades (Santich, 2004), but in Vojvodina only recently, with still insufficient awareness among employees in tourism industry about its benefits for development of the region (Kalenjuk, et al., 2013a; Kalenjuk, et al., 2013b). In the previous development policies and concepts that are related to the development of tourism, gastronomy, ie. food for locals and tourists, has not received an adequate development role, as opposed to its primary role (Kalenjuk, et al., 2011).

Food is an integral part of every tourist product, regardless of the form of tourism. Whether it is about board spending in restaurants, gourmet enjoyment in food and drink, culinary events, culinary schools, or purchase of agricultural, culinary and gastronomic products, (also as a souvenir) by tourists. Certainly the most significant is food consumption in tourism in order to meet basic energy and biological needs of tourists. But the development and standards of food for tourist are not always determined by tourism policy, but national, economic, agricultural and food policies (Hjalager, Corigliano, 20oo). Thus the food has become recognized as (Hall, Mitchel, 2001):

- part of the local culture, which tourists spend;

- part of tourism promotion;

- potential component of the local agricultural and economic development, and

- regional factor affected by consumption patterns and observed desires of tourists.

Food preparation and consumption in tourism is specific as it represents physical and material products with specific shape, color, texture, taste and smell, which can be stored and preserved, unlike services that do not have physical attributes, are elusive and intangible and can tourists cannot take services with them (Kalenjuk, et al., 2012f, which makes it a multifunctional attraction. Therefore, food is a tangible material component of the tourism product.

Quan and Wang (2004) give four recommendations in order to develop the food as an attraction of rural areas:

- promotion of gastronomy of certain rural areas (most often through the hospitality offer);

- transforamtion of food products into the main tourist attractions (schools of cooking, sale of souvenirs);

- foods of the destionation may also be a part of a larger tourist event (tourist food events) and;

- food can be used to improve the attractiveness of the destination (rural households, farms, culinary museums, etc.).

As opposed to many other forms of tourist movement, gastronomic destinations are usually available year-round at all hours and in all weather conditions (Richards, 2002), which gives priority to the development of this form of tourism. 


\section{Resources of gastronomic tourism}

Ignatov and Smith (2006) classified: facilities, activities, events and organizations in gastronomic tourism.

Facilities and land are those capacities that are engaged in the production and processing of food. Land use includes public access to land or landscape that tourists can see and certain routes through culinary regions, facilities and restaurants.

Activities attract culinary tourists beside the opportunity to consume food and drink - dining in restaurants or gestation of wines, spirits and beers. Additional activities include education, such as attending culinary schools, participation in a wine tasting, or individual reading magazines (journals) and books devoted to food.

Events include consumer events with focus on agricultural, culinary and gastronomic products (such as cheeses, desserts, wines, etc.), cooking equipment and food and wine festivals.

An organization includes those subjects which serve the interests of culinary tourists and support market development of culinary tourism, namely: associations and societies. Those contribute to the long-term development (growth) and promotion of culinary tourism in different ways (Ignatov, Smith, 2006).

\section{Metodology}

Research of gastronomic potentials in rural areas was conducted with the use of more recent literature dealing with gastronomic tourism with extensive various primary and secondary research conducted in rural areas of the region of Vojvodina. For the purposes of this paper we summarized results as a review of real situation, followed by criticism of all resources for development in rural areas, which are the basis for the improvement of the region.

Autonomous Province of Vojvodina as a place of research is located in the north of the Republic of Serbia and occupies an area of $21.614 \mathrm{~km}^{2}$ with 1.779 .128 hectares of agricultural land. According to the census of 2011 it is inhabited by a population of 1.912 .095 (Statistical Yearbook of R. Serbia, 2011) in 467 settlements, organized in 45 municipalities, 52 villages are urban and the rest of 4.15 is consisted of rural settlements where live $44.3 \%$ of total population (Census of Population, Households and Dwellings in R. Serbia, 2011).

The survey is divided into five phases and in each were used certain methods adapted to the type of collected data.

Firstly, we explored attractive cultural and historical destinations of rural areas that may be of interest to tourists. The study was conducted on a $100 \%$ sample and we analyzed all the museums, cultural and historical institutions that can be used to develop gastronomic tourism.

Then we researched destinations whose natural qualities can be interesting for gastronomic tourists from the perspective of production and supply of food. This section analyzes the wine districts, nature reserves, restaurants on rivers and in forests which offer authentic gastronomic experiences.

As the offer of food in restaurants is a key element in development of tourism, we carried out an analysis of the menus offered by rural restaurants sorting food in local, national and international dishes. We sampled offers in 87 facilities that are located in rural areas whereby we statistically processed and graphically presented the state of offers based on sampled 6.011 dishes from their offer. 
Food with protected designation of origin due to its specificity gives to region additional incomes and these products were explored on the territory of the rural areas of Vojvodina, isolating from the entire area products protected at the state level.

Finally, considering the significance of tourism food events with regard to the promotion of various agricultural, culinary and gastronomic products and attracting tourists we analyzed their structure and offer. In 2014, in rural areas took place 135 tourist events that are below statistically processed and graphically displayed.

\section{Results and discussion}

\section{Attractive cultural and historical destinations of rural areas of Vojvodina for gastronomic tourists}

Long has defined the culinary tourism as an activity of exploration and discovery of culture and history through food (Long, 2004), which in Vojvodina can be achieved by visiting museums, farms, ethno-houses and households in villages that by their preserved authenticity might be interesting for visitors.

Among the museums that may be interesting for gastronomic tourists in villages there are: the Museum of bread and the Museum of beer.

Serbian Museum of Bread in Pećinci deals with collection, protection, preservation and presentation of objects that were once used in Serbia in the production of bread. The basic concept of setting aims to show the way of grain of wheat from land to bread.

The Museum of beer in Čelarevo is designed to tell its 116 years long history since the founding of the brewery, where it opened a small visitor center. The museum is dedicated to the founder of the brewery, the famous landowner Lazar Dundjerski. This unique mini-center, which is a blend of traditional and modern, introduces visitors to the story, about the first beer created in this factory, the ways of procurement of the ingredients needed to make beer, and then the ways of storing and keeping beer. History of the brewery can be seen through old pictures and letters of the founder, as well as ways of entertainment of workers during the celebrations. Very rare antiques that even did not been collected by the nearby museums, were sought in locations around Celarevo so that the museum exhibits catering equipment that was used 100 years ago.

According to studied data by the tourism organizations, in the municipalities of Vojvodina there are 34 farms, 40 ethno-houses and 24 rural households differently distributed in the region. This number of authentic objects should provide to gastronomic tourists the enjoyment of the local specialties of Vojvodina, learning and participation in the preparation of authentic regional dishes and winter stores.

\section{Attractive natural of contrysides in Vojvodina for gastronomic tourists}

Hall and Mitchel (2002) suggest that gastronomic tourism is developing in areas where there was no change in the way of food and beverage production, where the emphasis is on the natural characteristics of the area. Prominent among them are: natural reserves, wine regions, buildings near rivers, lakes and hunting grounds in the region.

In Vojvodina, there are 14 special nature reserves. Prominent among them are Special Nature Reserve „Zasavica“, located near Sremska Mitrovica, known for cultivating special pig 
breed called mangulitsa, which meat has a high-quality nutritional composition, and meat of donkey, which milk gives perhaps the most expensive cheese in the world ( $1 \mathrm{~kg}=1$ ooo euro). Economic opportunities open through breeding omangulitsa and production of traditionally produced fermented sausages (Zekić, et al., 2012) and other meat products, as well as through the production of cheese from milk of donkeys bred in the reserve, which makes this reserve an important destination in the development of gastronomic tourism.

Hall et al. explained that wine tourists are significant consumers not only of wine, but also of local food (Hall, et al., 20oo), and Wolf in favor of it states that the wine tourism develops in natural areas with conditions favorable for the development of viticulture and defines it as a subset of gastronomic tourism (Wolf, 2006). Thus authentic natural areas for the development of gastronomic tourism are wine regions and vineyards, what Vojvodina is famous for.

Numerous rivers and lakes located in Vojvodina have influenced the formation of habits in the consumption of fish dishes. Specialties are made of different species of fish that inhabit these waters: carp, perch, catfish, sturgeon, pike, bream, Prussian carp, barbel, silver carp, brown bullhead and others. On the watercourse of Danube from Bezdan to Beška there are more than thirty cottages on the water, which give their visitors the opportunity to enjoy the Vojvodina fish dishes.

The hunting grounds with their hospitality facilities and authentic hunting offer can be used in the development of tourism in Vojvodina. Thanks to its preserved nature, in Vojvodina there are about 115 hunting grounds with hospitality facilities that besides accommodation offer the possibility to enjoy the specialties of hunted large and small game, prepared in a traditional way.

\section{Structure of food in restaurant in rural areas of Vojvodina}

McKercher et al. (2008) emphasize the importance of local, authentic dishes and the formation of a unique offer in the restaurants for the successful development of gastronomic tourism. Accordingly it was performed classification and analysis of food according to their origin, dividing them into: local, national and international (Tešanović, et al., 2010; Vuksanović, et al., 2012). The research was conducted on a sample of 10,923 dishes in 147 restaurants all over Vojvodina, taking into consideration meals in the facilities in villages, analysis was performed on a sample of 87 facilities and 6,011 dishes (Figure 1).

Based on the obtained data praiseworthy is the share of national dishes in some groups, but the share of local specialties is not satisfactory in terms of the development of gastronomic tourism, in relation to food from other parts of the world, which are internationally recognized.

Looking at the overall offer in restaurants of Vojvodina the share of national dishes is significant and it amounts to $40 \%$. The share of local dishes and creations of catering establishments themselves is unsatisfactory and it is only $12 \%$ (Figure 2), which can be corrected by introducing authentic dishes, typical for rural households and traditional Vojvodina cuisine.

It has been shown that service users who visit restaurants with national motifs often seek authentic national cultural experiences and the authenticity of the restaurant has a crucial influence on their satisfaction (Wood, Munoz, 2007). If we take into account the recommendations of the authors it can be concluded that the total offer at the regional level is partially satisfactory, because of the satisfactory number of national specialties. For successful development of gastronomic tourism, some restaurants need to increase number of local, authentic dishes. 


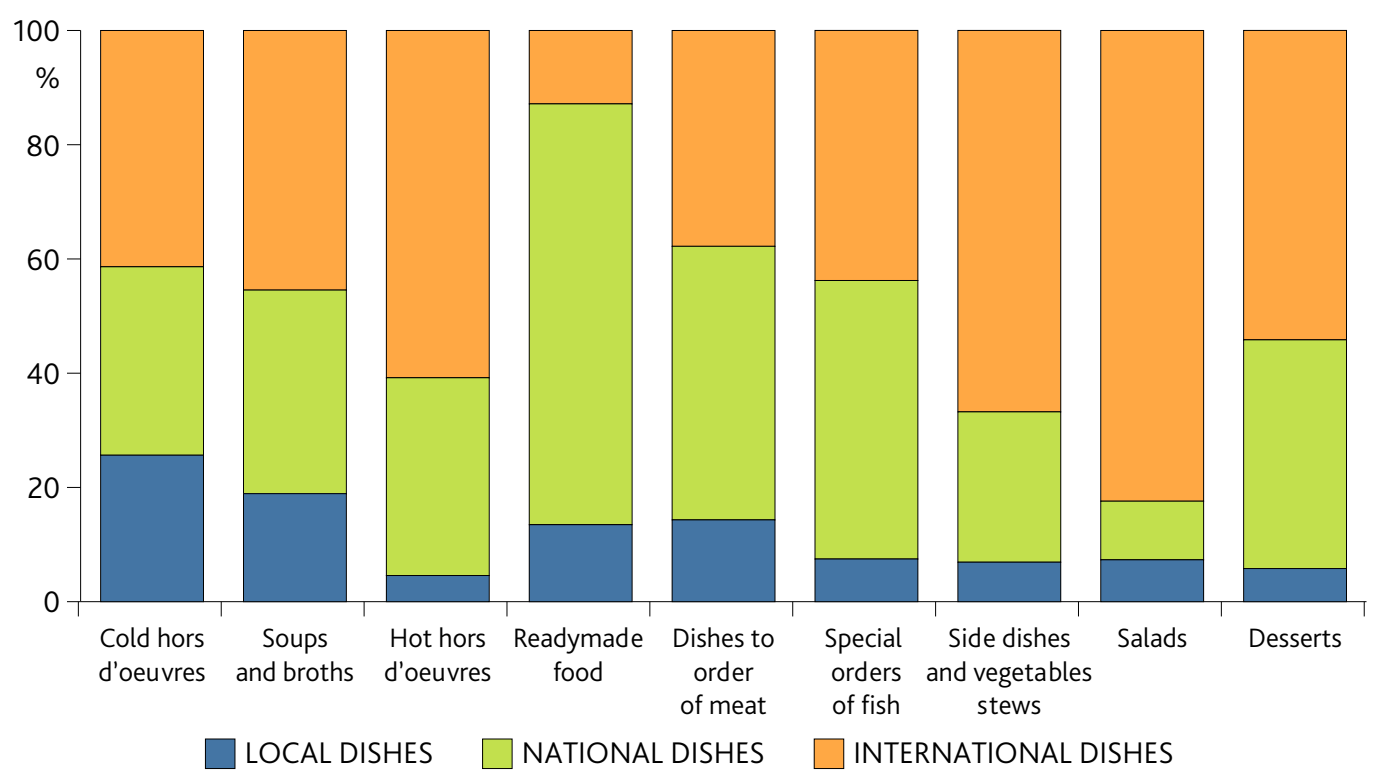

Figure 1. Structure of offer by type of dish

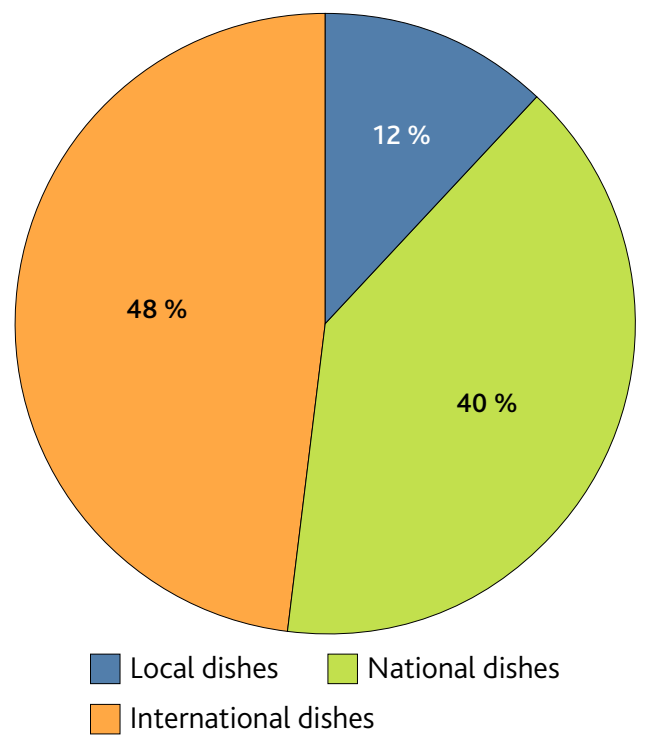

Figure 2. Overall structure of dishes in Vojvodina

\section{Foods and beverage with protected designation of orgin in Vojvodina}

Legal protection of geographical indications represent an opportunity for development of the national economy, bearing in mind that Vojvodina is an agricultural region (Kalenjuk, et al., 2014b). In the Intellectual Property Office of the Republic of Serbia an indication of geographical origin in Vojvodina have 17 products (Figure 3): Protected products in Vojvodina: 1. Spicy sausage - Kulen from Srem, 2. Domestic sausage from Srem, 3. Salami sausage from Srem, 4. Riesling from Banat, 


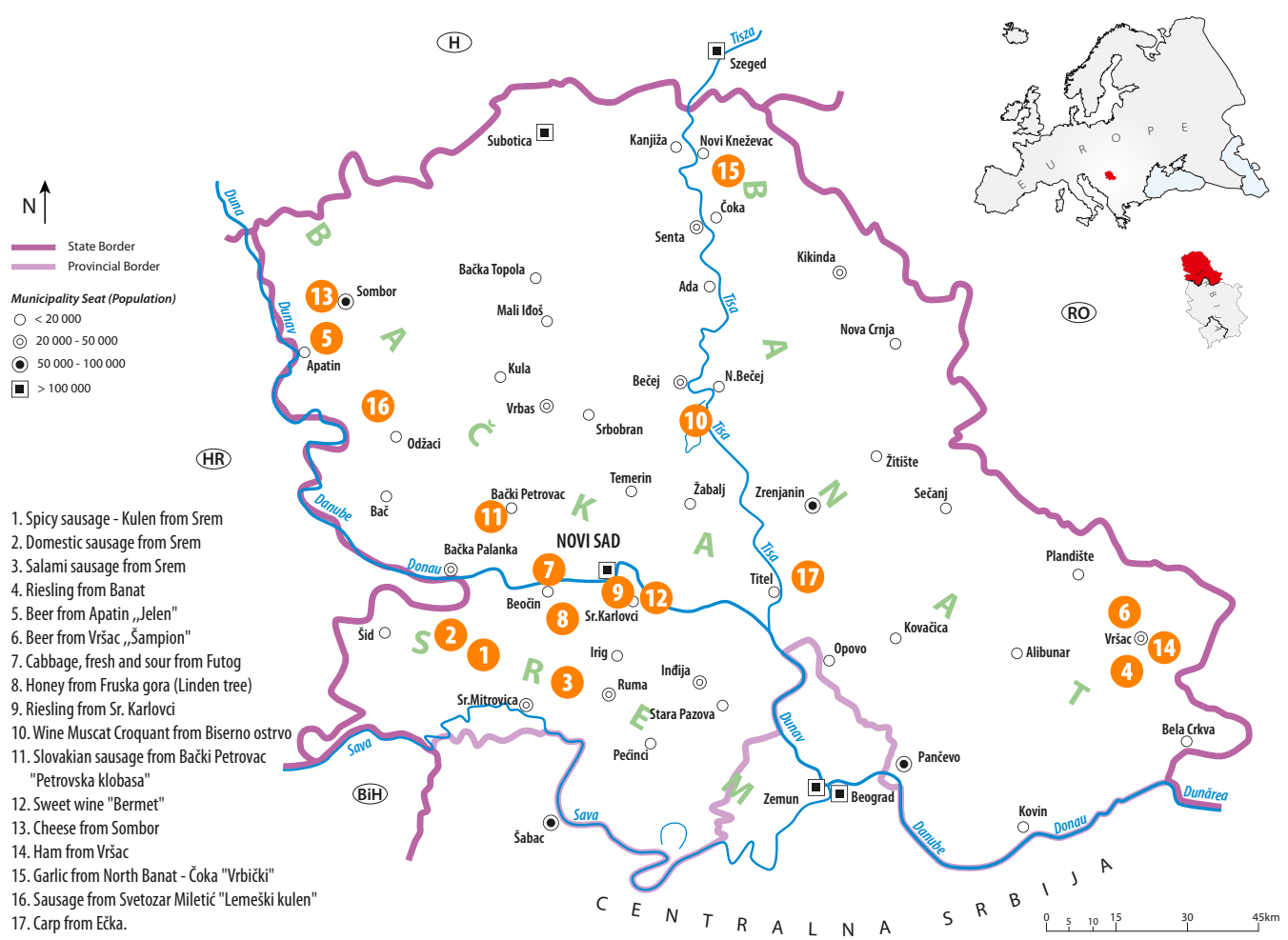

Figure 3. Protected products in Vojvodina

(Source: Kalenjuk \& Lazić)

5. Beer from Apatin „Jelen", 6. Beer from Vršac „Šampion", 7. Cabbage, fresh and sour from Futog, 8. Honey from Fruska gora (Linden tree), 9. Riesling from Sr. Karlovci, 10. Wine Muscat Croquant from Biserno ostrvo, 11. Slovakian sausage from Bački Petrovac "Petrovska klobasa", 12. Sweet wine "Bermet", 13. Cheese from Sombor, 14. Ham from Vršac, 15. Garlic from North Banat - Čoka "Vrbički", 16. Sausage from Svetozar Miletić "Lemeški kulen" and 17. Carp from Ečka.

The number of such products could be higher as well as the possibility of their purchase. Among the products there are none that is protected at EU level, and as such they have a much higher sale value and recognisability in the world.

\section{Tourist events of food and beverage in Vojvodina}

Number of gastronomic events in the world is constantly growing along with the growth of interest in gastronomic tourism as an interesting form of recreation and tourist attraction (Lee, Arcodia, 2011). Significance of events is reflected in the fact that gastronomic tourism is not of seasonal character, and that its activities can be realized throughout the year and at any time of the day, as stated Richards and in all weather conditions (Richards, 2002). In 2015, the total number of events that are dedicated exclusively to food or drink, and events where food and drink is one of the segments of events amounts to 224, in villages 135 events take place. The largest number of events based primarily on food is $51 \%$, while $41 \%$ of events where food or drink is integral part of an organization that has a different theme character, most often are ethno-festivals (Kalenjuk, et al., 2012c; Kalenjuk, et al., 2012d) (Figure 4). 


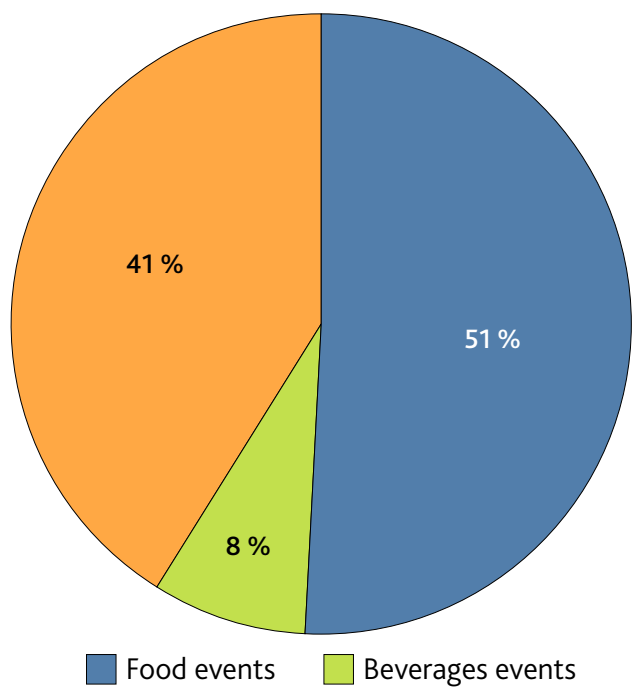

Events where food and drink one of the segments

Figure 4. Structure of type of events in Vojvodina

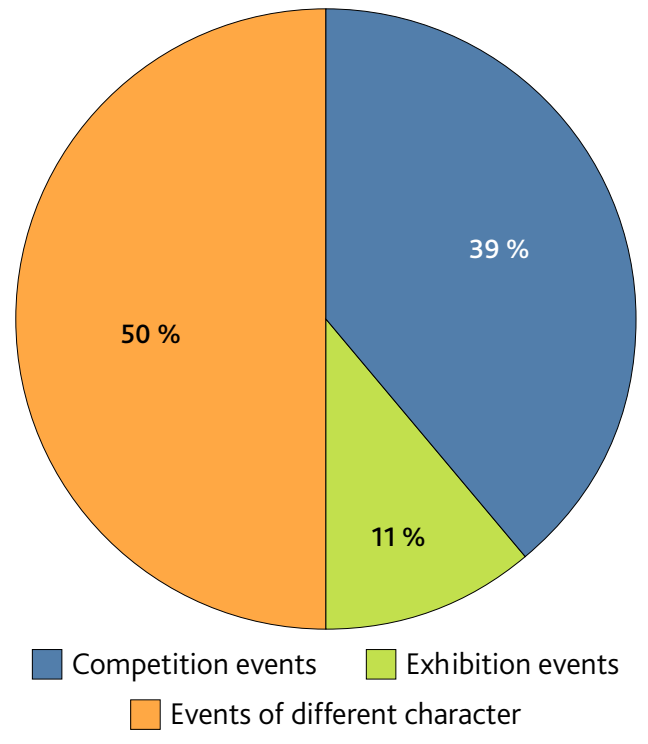

Figure 5. Structure of type of events in Vojvodina

With the view of tourist events: $39 \%$ has a competitive character, mainly in the preparation of Vojvodina's national dishes such as fish soup, goulash, stew, beans and the like, $11 \%$ have exhibition character, where the most frequent are exhibitions and gustation of local, autochthonous wines and spirits (Figure 5), 50\% have a different character, with food and drink as integral and inevitable part of events and offers which are based on local specialties.

\section{Practical contribution of research}

Studying and observing the trends of the place and role of authentic foods and beverages of developed tourist destinations in the world, it is observed the problem of non-systemic, Insufficient and clearly undefined approach to more successful putting food potentials of Vojvodina in active function of tourism development in the village. Those results represent a good practical basis to all relevant government entities, competent institutions, NGOs and tourist organizations at local, regional and national level, for implementation of operational plans and definition of development strategies that ensure more effective use of existing potential in the country, whereby the more attention would be paid to the affirmation of authentic food and drinks and the development of gastronomic tourism, which would lead to an increase in profits and community development.

Great benefit will be gained by businesses in the hospitality industry that will affect the structure and distribution of authentic dishes and drinks and present its significance in the offer. Tourist organizations and agencies will be encouraged due to results to use authentic food in marketing campaigns and in organization of new creative programs of gastronomic trips. In addition to affirming geographically already protected products, it will provide a major contribution to defining a large number of authentic products that should be protected in Vojvodina. Results of gastronomic events and their distribution in the region will highlight the great potential and possibilities for expansion of this form of tourism. 


\section{Conclusion}

Vojvodina is traditionally an important food producer in Serbia and the entire region. Due to its geographical location, relief, climate and cultural heritage, it created many distinctive, authentic dishes, food products and beverages that are produced in the industry, prepared in restaurants and used for nutrition of the population and export. These potentials are not sufficiently exploited for tourism development, although they represent an important resource. Many countries in the world put their food industry into function of tourism organizing gustation and into menus of restaurants introduced and specially highlight a range of local regional dishes, protected the origin of their signature products, made museums that promote gastronomic cultural heritage, organized numerous gastronomic events that gather even millions of people, organize tourist cooking schools and undertake a range of other activities that promote their own food and drink, developing thus a special form of tourism which they called a gastronomic tourism.

On the basis of the research on potentials of rural areas of Vojvodina for the development of gastronomic tourism and consultation of relevant, contemporary literature about successful emirical examples we came to the following conclusions:

- Vojvodina has attractive cultural, historical and natural destinations that can attract tourists to its villages.

- Food offer in Vojvodina is authentic, but requires supplementation with an emphasis on local food from rural households.

- Protected products have their own specific features that distinguish them from similar products which sould be used in tourism.

- Tourist events are the best way to attract tourists to the villages and the promotion of different agricultural, culinary and gastronomic products.

As Vojvodina is a tourism cluster of Serbia and an important economic region, greater recognition of authentic, distinctive, regional food and drink in tourism will contribute to increasing the economic potentials in rural areas, thus contributing to the development of local communities.

\section{Acknowledgments}

The work is part of research projects: III-046009 and III-046005 funded by the Ministry of Science and Technological Development of Republic of Serbia, and Provincial Secretariat for Science and Technological Development of the Vojvodina Province, No. 114-451-2539/2016-02.

\section{References}

Baum, S. 2011. The Tourist Potential of Rural Areas in Poland. Eastern European Countryside 17, 107-135.

Boniface, P. 2003. Tasting Tourism: Travelling for Food and Drink, Ashgate, Aldershot.

Census of Population, Households and Dwellings in R. Serbia 2011.

Hall, C.M. 2003. Wine, Food and Tourism Marketing, The Haworth Hospitality Press, New York, NY. 
Hall, C.M., Johnson, G., Cambourne, B., Macionis, N., Mitchell, R., Sharples, L. 200o. Wine tourism: An introduction, In: C. M. Hall, L. Sharples, B. Cambourne, N. Macionis, R. Mitchell, G. Johnson (Eds.), Wine tourism around the world: Development, management and markets (1-24), Butterworth Heinemann, Oxford.

Hall, C.M., Mitchell, R. 20o1. Wine and food tourism, In: Douglas, N., Douglas, N., Derrett, R. (eds.) Special Interest Tourism. John Wiley \& Sons Australia, Milton.

Hall, C.M., Mitchell, R. 2002. The changing nature of the relationship between cuisine and tourism in Australia and New Zealand: from fusion cuisine to food networks, In: A.M. Hjalager and G. Richards (Eds.), Tourism and Gastronomy (188-206), Routledge, London.

Hall, C.M., Mitchell, R. 20o6. Gastronomy, food and wine tourism, In: Buhalis Dimitrios, Costa Carlos, Tourism Business Frontiers - Consumers, products and industry, Elsevier Ltd, Oxford.

Hall, C.M., Mitchell, R. 20oo. We are what we eat: Food, Tourism and Globalization. Tourism, Culture and Communication 2-1, 29-37.

Henderson, J.C. 2004. Food as a tourism resource: A view from Singapore. Tourism Recreation Research 29-3, 69-74.

Hjalager, A.-M., Corigliano, M.A. 20oo. Food for tourists - determinants of an image. International Journal of Tourism Research 2-4, 281-93.

Hjalager, A.-M., Richards, G. 2002. Tourism and Gastronomy, Routledge, London.

Ignatov, E., Smith, S. 2006. Segmenting Canadian culinary tourists. Current Issues in Tourism 9-3, 235-255.

Kalenjuk, B., Đerčan, B., Tešanović, D. 2012a. Gastronomy tourism as a factor of regional development. Ekonomika 3-2012, 136-146. (in Serbian with English summary) http://www.ekonomika.org.rs/sr/PDF/ekonomika/2012/3-2012.pdf

Kalenjuk, B., Tešanović, D., Rudić, LJ., Korbatfinski, M., Gagić, S., Vuksanović, N. 2012b. The gastronomic potential of Northern Bačka in function of gastronomy tourism. Researches Review of the Department of Geography, Tourism and Hotel Management 41, 337-349. http:// www.dgt.uns.ac.rs/zbornik/issue41.php

Kalenjuk, B., Čomić, Đ., Tešanović, D., Armenski, T., Škrinjar, M. 2012c. Tourists manifestations in the development of culinary tourism in Vojvodina. 21st Biennial International Congress, Tourism \& Hospitality Management 2012, University of Rijeka, Faculty of tourism and hospitality management, Opatija, Croatia, 3 - 5 May 2012, Conference Proceedings, 316-322.

Kalenjuk, B., Tešanović, D., Gagić, S., Vuksanović, N., Škrinjar, M. 2012d. Tourism manifestation in the culinary tourism in Banat (Vojvodina, Serbia). Geographica Timisiensis 2-2012, on line. http://www.geografie.uvt.ro/old/cercetare/publicatii/geographica/new/on-linefirst.htm

Kalenjuk, B ., Tešanović, D., Korbatfinski, M., Gagić, S., Vuksanović, N., Petrović, M., Ivkov, M. 2012e. Products with origin and their significance for the development of gastronomic tourism in Vojvodina. Trends and challenges in food technology, nutrition, hospitality and tourism, 2nd International Professional Conference Proceedings, November 16th-17th 2012, Ljubljana, Slovenia, $349-358$.

Kalenjuk, B., Tešanović, D., Škrinjar, M., Đeri, L. 2012f. The importance of authentic food in the development of the culinary tourism in Vojvodina. 1st Belgrade International Tourism Conference 2012: Contemporary Tourism - Wishes and Opportunities, March 22-24, 2012. College of tourism. Belgrade, 293-300.

Kalenjuk, B., Tešanović, D., Gagić, S., Babić, J. 2013a. Views of employees in the hospitality and tourism industry on the total potencials of Vojvodina to attract tourists motivated by food 
and drink. Researches Review of the Department of Geography, Tourism and Hotel Management 42-2013, 178-188. http://www.dgt.uns.ac.rs/zbornik/issue42/en/15\%2oKalenjuk.pdf

Kalenjuk, B., Tešanović, D., Bradić, M. 2013b. The employees attitudes in hospitality and tourism and about potential for development of gastronomic tourism in Vojvodina. DETUROPE 3-2013, 31-44. http://www.deturope.eu/img/upload/content_76015353.pdf

Kalenjuk, B., Tešanović, B. 2013c. Determination for strategic development of gastronomic tourism in Vojvodina. Ekonomika 59-4, 195-202. http://www.ekonomika.org.rs/Ekonomika.html

Kalenjuk, B., Tešanović, D., Gagić, S. 2014a. Regional development of tourist destinations through the development of gastronomic tourism. Since the crisis on development, the 4th International Scientific Conference, BIH, University of Business Studies 24.10., 363-374. http://univerzitetps.com/images/stories/aktuelnosti/konferencija_od_krize_prema_razvoju/zbornik/index.html

Kalenjuk, B., Tešanović, D., Gagić, S., Knežević, M. 2014b. Importance of Food With Protected Origin and Attitudes of Employees Towards the Development of Gastronomic Tourism. Tourism Education Studies and Practice 3-3, 99-107. http://ejournal10.com/journals_n/1418476423.pdf

Kalenjuk, B., Tešanović, D., Škrinjar, M., Vuksanović, N. 2011. Gastronomy potentials of Vojvodina in the development of the tourism. Researches Review of the Department of Geography, Tourism and Hotel Management 40, 180-187. http://www.dgt.uns.ac.rs/zbornik/ issue $40 / 14 \% 20 K a l e n j u k . p d f$

Lee, I., Arcodia, C. 2011. The Role of Regional Food Festivals for Destination Branding. International Journal of Tourism Research 13-4, 355-367.

Long, L.M. 2004. Culinary Tourism, The University Press of Kentucky: Lexington.

McKercher, B., Okumus, F., Okumus, B. 2008. Food tourism as a viable market segment: it's all how you cook the numbers! Journal of Travel \& Tourism Marketing 25-2, 137-148.

Quan, S., Wang, N. 2004. Towards a structural model of the tourist experience: an illustration from food experiences in tourism. Tourism Management 25-3, 297-305.

Richards, G. 2002. Gastronomy: an essential ingredient in tourism production and consumption? In: A.-M. Hjalager \& G. Richards (Eds.), Tourism and Gastronomy (3-20), Routledge, London.

Santich, B. 2004. The study of gastronomy and its relevance to hospitality education and training. International Journal of Hospitality Management 23, 15-24.

Statistical Yearbook of the Republic of Serbia 2014. http://pod2.stat.gov.rs/ObjavljenePublikacije/God/SGS2014.pdf

Stojanović, T., Čerović, S. 2008. Gastronomic offer of rural tourism: Tourist attraction of geographic area of Serbia. Collection of papers, Faculty of Geography at the University of Belgrade 56, 165-176. http://zbornik.gef.bg.ac.rs/pdf/radovi/97.pdf

Tešanović, D., Vićić, S., Kalenjuk, B. 2010. Structure and quality local cuisine in a recognizable serbian regional hospitality facilities. The Second International Scientific Expert Conference, Quality and innovation in tourism and catering, 2010, Bled, Slovenija, 515-526.

Vuksanović, N., Kalenjuk, B., Tešanović, D., Gagić, S. 2012. Research of catering offers in order to develop gastronomic tourism of Srem (A.P. Vojvodina). National College „Liviu Rebreanu", Bistrita, 16th of June, 236-244.

Wolf, E. 2006. Culinary Tourism: The Hidden Harvest, Kendall/Hunt Publishing, Dubuque.

Wood, N.T., Mu'noz, C.L. 2007. 'Norules, justright'orisit? The role of the med restaurants as cultural ambassadors. Tourismand Hospitality Research 7-3/4, 242-255.

Zekić, V., Tomović, V., Milić, D., Lukač, D. 2012. Comparison of economic characteristics of porkers of Mangalitsa and Yorkshire race. Economics of Agriculture 59-4, 649-656. 